\title{
Primary cutaneous adenoid cystic carcinoma of the eyelid and literature review
}

\author{
Carcinoma adenóide cístico cutâneo primário de pálpebra e revisão da literatura
}

\author{
Deniz Turgut Coban ${ }^{1}$, Muhammet Kazim Erol ${ }^{1}$, Dinc Suren², Birsel Tutus ${ }^{2}$
}

\begin{abstract}
Primary cutaneous adenoid cystic carcinoma (PCACC) is a rare malignant epithelial tumor most commonly observed in the scalp and skin of the chest and originating from the palpebral portion of the lacrimal gland in the orbit. Here we describe the diagnosis and treatment of a rare case of PCACC in an eye of a 52-year-old male. The patient presented with a mass lesion of the right lower eyelid. During incisional biopsy, lack of encapsulation and a secretion pattern different to that of chalazion was observed, which differentiated the lesion from chalazion. Pathological analysis revealed the diagnosis of PCACC. This case highlights the importance of careful inspection for macroscopic differentiation of PCACC from chalazion after initial surgery and pathological evaluation of all surgically removed mass lesions for accurate diagnosis and treatment.
\end{abstract}

Keywords: Chalazion; Adenoid cystic carcinoma; Eyelid neoplasms; Macroscopic diagnosis

\begin{abstract}
RESUMO
O carcinoma adenóide cístico cutâneo primário (PCACC) é um tumor maligno epitelial raro, mais comumente observado no couro cabeludo e na pele do peito sendo originário da porção palpebral da glândula lacrimal na órbita. Apresentamos o diagnóstico e tratamento de um caso raro de carcinoma adenóide cístico cutâneo primário do olho em um paciente do sexo masculino de 52 anos de idade, com uma lesão maciça da pálpebra inferior direita. A observação da falta de encapsulamento e um padrão de secreção diferente do calázio durante biópsia incisional permitiu a diferenciação da lesão de um calázio. A avaliação dos resultados do exame patológico resultou no diagnóstico de carcinoma adenóide cístico cutâneo primário. A análise do caso indica a importância de uma inspeção cuidadosa para a diferenciação macroscópica da carcinoma adenóide cístico cutâneo primário do calázio após a cirurgia iniciale avaliação patológica de todas as lesões de massa removidas cirurgicamente para o diagnóstico e tratamento corretos.
\end{abstract}

Descritores: Calázio; Carcinoma cístico de adenóide; Neoplasias palpebrais; Diagnóstico macroscópicos

\section{INTRODUCTION}

Adenoid cystic carcinoma (ACC) is an epithelial tumor seen mainly in the major salivary glands and rarely in the minor salivary glands, esophagus, bronchial glands, skin, breast, lungs, vulva, cervix, and prostate ${ }^{(1-3)}$. First described by Boggio et al. in 1975, primary cutaneous ACC (PCACC) is a rare type of ACC, with only approximately 60 PCACC cases reported in the literature ${ }^{(4-6)}$. Although PCACC has traditionally been considered to originate from the eccrine glands, novel data collected through pathological evaluation indicates that PCACC is of apocrine origin: PCACC may originate from the primary accessory glands of the conjunctiva, ectopic lacrimal gland, and adnexal gland; and it is located in the middle and deep dermis, not continuing into the epidermis ${ }^{(4-6)}$.

PCACC is most commonly observed in the scalp, which may delay diagnosis, as well as the skin of the chest, and it is usually accompanied by alopecia. PCACC usually grows slowly as a flesh-colored, 0.5-0.9-cm, nodular mass without redness or ulceration, although it may be accompanied by hair shedding and irregularity in shape. The mean duration between the onset of disease and diagnosis is 10 years, and patient mean age at the time of detection is 59 years ${ }^{(6)}$. Although local recurrence is frequently observed, distant metastasis of PCACC, mainly to the lungs, has rarely been reported ${ }^{(1,6)}$.

Although PCACC most commonly originates from the palpebral part of the lacrimal gland, eyelid involvement has also been observed. PCACC of the eyelid is very rare, and almost all cases described in the literature were treated surgically for chalazion and the diagnosis of PCACC was established either pathologically or due to postoperative recurrence ${ }^{(1,7)}$. To further explore the nature of and findings associated with PCACC, we present data on treatment of a case of PCACC admitted to our eye clinic presenting with mass lesions in the lower eyelid and review the scientific literature relevant to PCACC.

\section{CASE REPORT}

A 52-year-old male was admitted to the Oculoplasty Unit at the Antalya Research and Training Hospital complaining of a mass lesion in the right lower eyelid. The flesh-colored mass lesion measured $3 \times 4 \mathrm{~mm}$, was not causing significant irregularity in the eyelashes, and had grown slowly over approximately 4 years (Figure 1). Incisional biopsy was performed with a provisional diagnosis of suspected chalazion or tumor. Microscopic examination revealed a poorly circumscribed dermal tumor composed of basaloid cells with a glandular, cystic, and cribriform arrangement embedded in a loose fibrous stroma, in which the cystic spaces contained abundant alcian blue-positive ( $\mathrm{pH} 2.5$ ) mucin (Figure 2).

The cells covering the cystic spaces were arranged in two cell layers and had round, uniform nuclei; some with small, conspicuous, solitary nucleoli. Individual tumor cells had a scant amphophilic cytoplasm and high nuclear-to-cytoplasmic ratio (Figure 3). Mitotic activity was sparse and no perineural or lymphovascular invasion was observed. On immunohistochemical examination, the tumor cells stained positively for Cam 5.2 (low-molecular-weight keratin). The
Submitted for publication: November 11, 2014

Accepted for publication: January 15, 2015

Department of Ophthalmology, Antalya Education and Research Hospital, Antalya, Turkey.

2 Department of Pathology, Antalya Education and Research Hospital, Antalya, Turkey.
Funding: No specific financial support was available for this study.

Disclosure of potential conflicts of interest: None of the authors have any potential conflict of interest to disclose.

Corresponding author: Deniz Turgut Coban. Antalya Education and Research Hospital. Department of Ophthalmology - Antalya - 07100 - Turkey - E-mail: denizturgut48@yahoo.com 


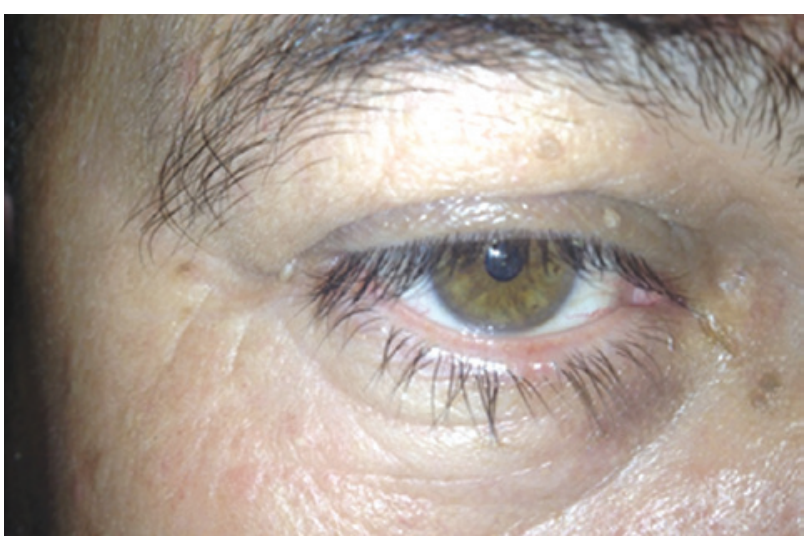

Figure 1. A mass lesion (PCACC) measuring $3 \times 4 \mathrm{~mm}$ near the right lower eyelid.

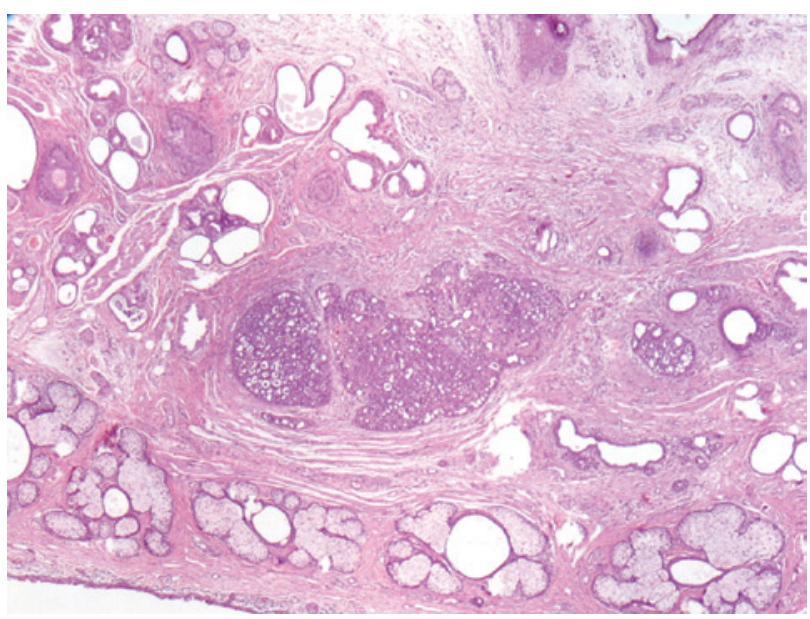

Figure 2. A poorly circumscribed dermal tumor showing a glandular and cribriform pattern in the dermis (H\&E staining, magnification $\times 40$ ).

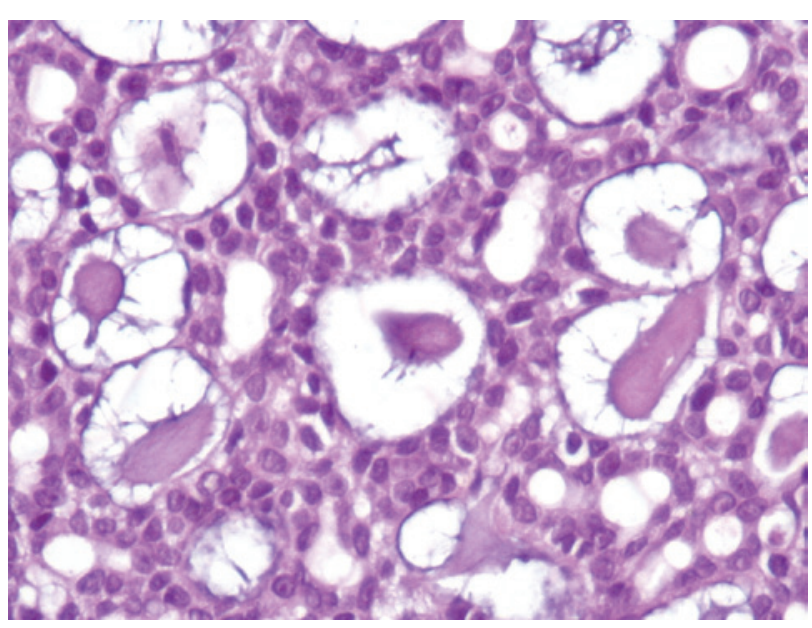

Figure 3. Cells covering cystic spaces showing arrangement in two cell layers (H\&E staining, magnification $\times 40$ ).

inner cell layer stained positively for CD117 (c-KIT), whereas the outer cell layer stained positively for smooth muscle actin (SMA; Figure 4). SMA expression in the outer cells was consistent with myoepithelial cell differentiation. Analysis of these pathological findings resulted in the diagnosis of PCACC.

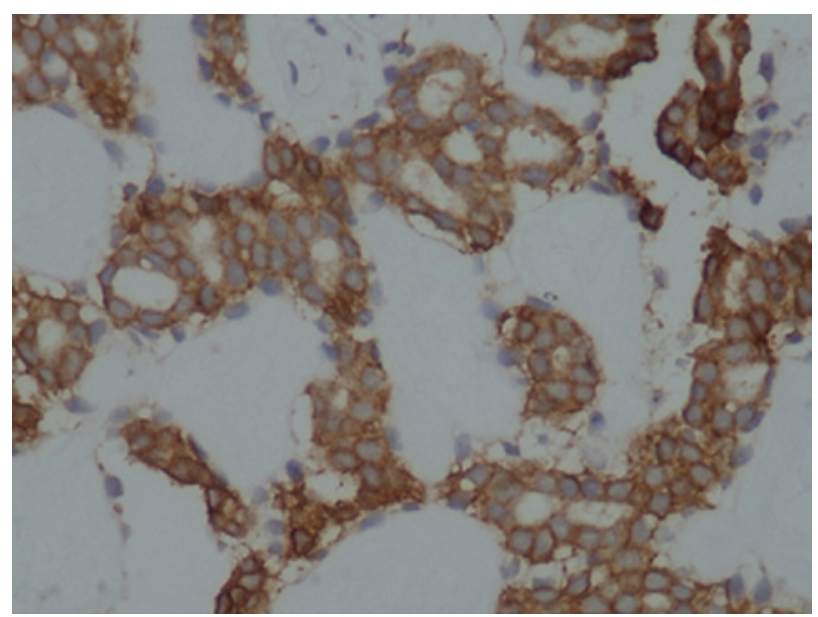

Figure 4. Inner cell layer showing CD117 (cKIT) positivity (magnification $\times 400$ ).

Physical examination revealed the absence of palpable lymph nodes in the head and neck region. A detailed oncologic assessment carried out to identify any close and distant foci and positron emission tomography-computed tomography revealed no metastasis. Based on these findings, large excision was recommended. Accordingly, the mass lesion was removed together with a 4-mm tumor-free margin. Reconstruction of the eyelid was performed with lateral canthotomy and a Tenzel semicircular flap. On pathological examination, the surgical margins appeared clean, and no perineural invasion was observed.

\section{DISCUSSION}

Although most commonly observed in the major salivary glands, ACC may also be seen in the minor salivary glands, esophagus, bronchial glands, skin, breast, lungs, vulva, cervix, and prostate ${ }^{(2,3)}$. ACC is rarely seen in the palpebral part of the lacrimal gland, and even more rarely in the eyelids. PCACC is most commonly observed in the scalp and skin of the chest together with alopecia ${ }^{(8)}$. Cacchi et al. ${ }^{(6)}$ reported that the diagnosis of PCACC is typically made approximately 10 years after onset and at a patient mean age of 59 years. While Cavazza et al. ${ }^{(1)}$ reported that ACC of the eyelid characteristically emerges with painful nodules together with eyelash loss or irregularity, the mass lesion observed in our case was small and not accompanied by any significant eyelash changes or nodules. We hypothesize that this difference in appearance resulted from the establishment of diagnosis four rather than 10 years after onset and when the patient was 52 rather than 59 years of age.

In general, the prognosis of ACC of the salivary and lacrimal glands depends on various factors, including clinical stage, the location of the primary lesion, and the histologic growth pattern. ACCs may be classified into three different histologic variants-tubular, solid, and cribriform-according to their growth pattern. Among these variants, ACC with a solid growth pattern has a worse prognosis than ACC with a cribriform or tubular growth pattern ${ }^{(4)}$. Patients with ACC originating from the lacrimal gland have a particularly poor prognosis, even after extended radical excision and radiation. In a study of 362 cases of orbital tumors, 11 of which were ACC, Goto et al. ${ }^{(9)}$, reported that seven patients developed metastasis with or without treatment and six of whom died. Based on these findings, the authors concluded that the incidence of metastasis of cutaneous ACC originating from the eccrine gland is lower than that of extracutaneous ACC.

PCACC cases have also been reported to originate from skin and skin appendices. Among the nine cases reported by Cavazza et al. and Bui et al., two each originated from the primary skin, accessory lacrimal glands, and adnexal glands of the skin, respectively, while 
the origin of the remaining three was not reported ${ }^{(1,7)}$. Cavazza et al. ${ }^{(1)}$ concluded that both eyelids were equally involved, as four cases developed from the upper eyelid and four from the lower eyelid. In our case, examination of the adnexal tissues of the skin indicated that the PCACC originated from the adnexal glands of the skin.

Sentinel lymph node examination has been reported useful for assessment of invasion, as PCACC is known to be locally aggressive and prone to metastasis. In two PCACC cases originating from the scalp and nose, Kato et al. detected invasion by sentinel lymph node examination ${ }^{(2)}$. Nevertheless, Cavazza et al. were unable to detect invasion using sentinel lymph node examination in their study ${ }^{(1)}$. In our study, sentinel lymph node examination was not performed. Although local recurrence of PCACC is frequent, distant metastasis, mainly to the lungs, is rarely reported. In PCACC, perineural invasion has been reported to exceed 50\%, and recurrence after excision due to such invasion has been observed in $59 \%$ of cases $^{(1,6,7,10)}$.

In one study, Bui et al. detected perineural invasion in 3/9 cases originating from the eyelid ${ }^{(7)}$. Based on similar findings, some authors recommend following up cases with perineural invasion closely and for a longer duration and performing radiotherapy after therapy ${ }^{(10)}$. Despite new recommendations, chemotherapy and radiotherapy remain the recommended therapeutic options in cases where total removal is not possible $e^{(1,10)}$. In our case, neither perineural nor lymphovascular invasion was detected, and no other foci could be detected despite detailed examination. Therefore, no other therapies except surgical excision and the appropriate follow-up were recommended. The histogenesis of PCACC remains unclear, although it is considered apocrine when evaluated pathologically. In accordance with previous reports claiming that PCACC is located in the middle and profound dermis not continuing into the epidermis ${ }^{(6)}$, the tumor in our case was located in the dermis, did not continue into epidermis, and assumed a cribriform pattern composed of concentric cell groups and cell lines around the pseudocyst.

Observation of lymph node involvement and perineural invasion should be considered during differential diagnosis from tumors showing aggressive behavior ${ }^{(1)}$. As cases of chalazion are frequently observed, lesions mimicking chalazion may easily be overlooked. Almost all reported cases of eyelid PCACC were excised with a prediagnosis of chalazion followed by a diagnosis of PCACC after inci- sion biopsy, leading to recurrence or lack of recovery ${ }^{(1,7,9)}$. In our case, incisional biopsy was performed with a prediagnosis of suspected chalazion or tumor due to the absence of inflammation, macroscopic hyperemia, and proximity to the eyelid margin. In the intraoperative macroscopic evaluation, the lesion was differentiated from chalazion upon observation of a different secretion pattern and lack of encapsulation. The most important difference in our case was early diagnosis following initial surgery because of careful inspection and early macroscopic recognition.

In conclusion, an important consideration is the risk of misdiagnosing eyelid lesions mimicking chalazion as cases of chalazion rather than PCACC. The results of this study indicate that PCACC may be macroscopically discriminated from chalazion by careful inspection and early detection. More importantly, they indicate that all surgically removed mass lesions should be evaluated pathologically.

\section{REFERENCES}

1. Cavazza S, Laffi GL, Lodi L, Collina G. Primary cutaneous adenoid cystic carcinoma of the upper lid: a case report and literature review. Int Ophthalmol. 2012:32(1):31-5.

2. Kato N, Yasukawa K, Onozuka T. Primary cutaneous adenoid cystic carcinoma with lymph node metastasis. Am J Dermatopathol. 1998;20(6):571-7. Comment in: Am J Dermatopathol. 1999;21(4):400.

3. Sammour R, Lafaille P, Joncas V, Krasny M, Wong J, Allaire G, et al. Adenoid cystic carcinoma of the eyelid: a rare cutaneous tumor treated with Mohs micrographic surgery. Dermatol Surg. 2009:35(6):997-1000.

4. Naylor E, Sarkar P, Perlis CS, Giri D, Gnepp DR, Robinson-Bostom L. Primary cutaneous adenoid cystic carcinoma. J Am Acad Dermatol. 2008:58(4):636-41.

5. Boggio R. Letter: Adenoid cystic carcinoma of scalp. Arch Dermatol. 1975;111(6):793-4.

6. Cacchi C, Persechino S, Fidanza L, Bartolazzi A. A primary cutaneous adenoidcystic carcinoma in a young woman. Differential diagnosis and clinical implications. Rare Tumors. 2011;3(1):e3.

7. Bui M, Frank SJ, Nasser QJ, El Sawy T, McLemore MS, Morrison WH, et al. Multidisciplinary management of primary adenoid cystic carcinoma of the eyelid with perineural invasion. Ophthal Plast Reconstr Surg. 2013;29(6)e143-6.

8. Van der Kwast T, Vuzevski V, Ramaekers F, Bousema MT, Van Joost T. Primary cutaneous adenoid cystic carcinoma: case report, immunohistochemistry and review of the literature. Br J Dermatol. 1988;118(4):567-77.

9. Goto H, Yamamoto T, Ishiyama Z, Usui M, Okada S. Adenoid cystic carcinoma arising from the lower eyelid. Jpn J Ophthalmol. 2006;50(4):374-6.

10. Feasel AM, Brown TJ, Bogle MA, Tschen JA, Nelson BR. Perineural invasion of cutaneous malignancies. Dermatol Surg. 2001;27(6):531-42. 